\title{
PERAN LKP MODELING “COLOUR MODELS MANAGEMENT YOGYAKARTA” DALAM MENGEMBANGKAN ASPEK PERSONAL DAN SOSIAL SISWA
}

\section{ROLES OF THE COURSE AND TRAINING INSTITUTE OF MODELING COLOUR MODELS MANAGEMENT YOGYAKARTA IN THE DEVELOPMENT OF LEARNER'S PERSONAL AND SOCIAL ASPECTS}

\author{
Nyudi Dwijo Susilo, Yoyon Suryono \\ LKP Colour Models Management Yogyakarta, Universitas Negeri Yogyakarta \\ nyudid@yahoo.com, yoyonsuryono@yahoo.com
}

\begin{abstract}
Abstrak
Penelitian ini bertujuan untuk mengetahui; (1) Pengelolaan kursus modeling di LKP Colour Models Management Yogyakarta. (2) Hasil pengembangan aspek personal dan sosial siswa modeling di Lembaga Kursus dan Pelatihan (LKP) Colour Models Management Yogyakarta. Penelitian ini mengunakan pendekatan kualitatif deskriptif. Subjek dari penelitian ini adalah pengelolaan yang meliputi kurikulum dan pembelajarannya, siswa, tenaga pendidik dan tenaga kependidikan di LKP Colour Models Management Yogyakarta. Pengumpulan data dilakukan dengan observasi, wawancara, dan dokumentasi. Analisis data menggunakan teknik analisis kualitatif menurut Miles dan Hubermann. Hasil penelitian menunjukkan sebagai berikut; (1) Tahapan pelaksanaan program kursus modeling dapat berjalan sesuai rencana. (2) LKP Colour Models Management Yogyakarta berperan langsung dalam mengembangkan aspek personal (kepribadian) siswanya. (3) LKP Colour Models Management Yogyakarta berperan langsung dalam mengembangkan aspek sosial siswanya.
\end{abstract}

Kata kunci: Modeling, pengembangan aspek personal dan sosial

\begin{abstract}
This study aims to investigate (1) the organization of modeling course in the Course and Training Institute (CTI) of Colour Models Management Yogyakarta and (2) the results of the development of personal and social aspects among the modeling learners in the Course and Training Institute (CTI) of Colour Models Management Yogyakarta.This study employed the qualitative descriptive technique. The research subject was the management comprising the curriculum and insctruction, learners and educators, and educational personnel in the CTI of Colour Models Management Yogyakarta. The data were collected through observations, interviews, and documents. They were analyzed using the qualitative analysis technique by Miles and Huberman.The research findings are as follows. (1) The phase of the modeling course program implementation runs as planned. (2) The CTI of Colour Models Management Yogyakarta plays a direct role in the development of the learners's personal aspect. (3) The CTI of Colour Models Management Yogyakarta plays a direct role in the development of the learners' social aspect.
\end{abstract}

Keywords: Modeling, development of personal and social aspects 


\section{PENDAHULUAN}

Lembaga kursus adalah salah satu satuan pendidikan nonformal. Pendidikan nonformal diselenggarakan bagi warga masyarakat yang memerlukan layanan pendidikan yang berfungsi sebagai pengganti, penambah, dan/atau pelengkap pendidikan formal dalam rangka mendukung pendidikan sepanjang hayat. Pendidikan nonformal berfungsi mengembangkan potensi siswa dengan penekanan pada penguasaan pengetahuan dan keterampilan fungsional serta pengembangan sikap dan kepribadian profesional. Sebagai bagian dari satuan pendidikan nonformal, lembaga kursus memiliki daya lentur dan fleksibilitas dalam memberikan pembelajaran terhadap masyarakat. Dalam pembelajarannya, lembaga kursus menyesuaikan dengan kondisi dan kebutuhan siswa, karena kursus dan pelatihan diselenggarakan bagi masyarakat yang memerlukan bekal pengetahuan, keterampilan, kecakapan hidup, dan sikap untuk mengembangkan diri, mengembangkan profesi, bekerja, usaha mandiri, dan/atau melanjutkan pendidikan ke jenjang yang lebih tinggi. Menurut Coombs (1974, p.8) pendidikan nonformal adalah :"... any organized, systematic, educational activity carried on outside the frameworkof the formal system to provide selectes types of learning to particular subgroups in the population" Pendidikan nonformal ialah setiap kegiatan terorganisasi dan sistematis, di luar sistem persekolahan yang mapan, dilakukan secara mandiri, yang memberikan alternatif pendidikan kepada sub-sub kelompok dalam masyarakat.

Kebanyakan dari Lembaga Kursus dan Pelatihan (LKP) hanya berorientasi pada bagaimana mencari siswa sebanyak-banyaknya, sehingga keuntungan bisa diperoleh. Semakin banyak siswa, semakin banyak pula keuntungan yang diperoleh, karena tidak dipungkiri biaya operasional LKP berasal dari pembayaran siswa. Lembaga kursus dianggap sukses apabila memiliki siswa yang banyak dan proses belajar mengajarnya berlangsung stabil. Sedangkan dari pihak siswa hanya berorientasi pada penguasaan ketrampilan tertentu dan juga pada perolehan sertifikat atau Surat Tanda Selesai Belajar (STSB). Dengan penguasaan jenis ketrampilan tertentu dan memiliki sertifikat atau STSB diharapkan bisa dengan cepat dan lebih mudah untuk mendapatkan pekerjaan tertentu sesuai dengan ketrampilannya tersebut, atau setidaknya setelah mengikuti kursus dapat membuka usaha mandiri/berwiraswasta yang nantinya bisa menjadi sumber penghasilan.

Orientasi pada penguasaan keterampilan tertentu dan perolehan Surat Tanda Selesai Belajar (STSB) dikhawatirkan akan menghambat perkembangan aspek personal dan sosial siswa, karena manusia pada dasarnya adalah makhluk sosial yang akan selalu berinteraksi dengan orang lain dalam kehidupan bermasyarakat. Dalam kehidupan bermasyarakat seseorang memiliki peran sosial sesuai dengan kemampuannya. Dalam perannya tersebut seseorang bisa diminta atau dipilih menjadi pemimpin atau wakil masyarakat dan juga bisa memiliki sebuah posisi pekerjaan yang baik karena memiliki kemampuan tertentu atau keterampilan tertentu.

Untuk dapat berperan secara tepat dalam kehidupan sosialnya, seseorang juga harus memiliki aspek personal (kepribadian) yang baik. Dengan memiliki kemampuan personal (kepribadian) yang baik seseorang bisa disukai atau dipercaya oleh orang lain atau masyarakat. Dalam hal ini kepribadian yang dimaksud adalah bagaimana cara seseorang berpikir, bersikap, berbicara, dan bertingkahlaku. Tanpa kematangan aspek personal dan sosial, seseorang tidak akan mampu menyelesaikan masalah-masalah kehidupan, meskipun seseorang memiliki pengetahuan dan kemampuan teknis. Darkenwald (1982, p.50) menjelaskan: "What adults want to learn and are constrained to learn... is generated by the social milieu in which they live. Their interests, their needs, their problems, and their ambitions are products of their environment"

Dari penjelasan di atas dapat disimpulkan bahwa apa yang orang dewasa ingin pelajari dihasilkan oleh lingkungan sosial di mana mereka tinggal. Kepentingan mereka, kebutuhan mereka, masalah mereka, dan 
ambisi mereka adalah produk dari lingkungan mereka.

Banyak lulusan dari SMU/SMK atau bahkan perguruan tinggi yang akhirnya tidak bisa mendapatkan pekerjaan karena mereka tidak memiliki soft skill (bagaimana cara berdandan, bagaimana cara berbicara, menguasai etiket pergaulan, dll), selain karena kompetensinya tidak sesuai dengan lowongan pekerjaan yang ada. Hal ini disebabkan karena pendidikan formal di negara kita lebih banyak menekankan kemampuan pengetahuan dan teknis saja kepada siswa. Padahal untuk mencapai keberhasilan dalam pekerjaan seseorang tidak hanya dibekali dengan pengetahuan dan kemampuan teknis saja, tetapi juga perlu dibekali oleh kematangan kepribadian yang mencakup aspek personal dan sosial. Dale Carneige (seorang ahli hubungan antarmanusia) mengatakan bahwa 15\% keberhasilan seseorang didalam bisnis ditentukan oleh pengetahuannya dibidang keteknikan dan $85 \%$ ditentukan oleh keterampilannya dalam pergaulan. Pergaulan dalam hal ini adalah bagaimana seseorang bisa membawa diri dalam masyarakat, hal ini berkaitan erat dengan aspek personal dan sosial seseorang (Modul Etika dan Kepribadian LKP Colour Models Management). Tanpa kematangan aspek personal dan sosial, seseorang tidak akan mampu menyelesaikan masalah-masalah kehidupan, meskipun seseorang memiliki pengetahuan dan kemampuan teknis.

Lembaga Kursus dan Pelatihan (LKP) Colour Models Management Yogyakarta sebagai salah satu bagian dari satuan pendidikan nonformal yang menyelenggarakan program pelatihan modeling plus, berusaha untuk menciptakan SDM yang tidak hanya professional di bidang modeling tetapi juga memiliki kepribadian yang baik dan rasa sosial yang tinggi. Hal ini bisa tercapai karena selain materi dalam bidang modeling, peserta didik juga diajarkan materi tentang pengembangan diri, grooming, etiket, public speaking, dan kewirausahaan. Menurut Sanggarwaty (2003, p.2) dunia model adalah dunia menjual jasa, dimana model menjadi mediator antara produsen dan konsumen. Keberadaan model dibutuhkan oleh desainer/produsen untuk berperan se- bagai pelaku yang mampu mengkomunikasikan busana/produk kepada konsumennya. Tugas model tidaklah ringan karena harus menciptakan atau menyampaikan image produk yang diperagakan kepada konsumen.

Materi yang diajarkan di LKP Colour Models Management Yogyakarta meliputi: catwalk, pose, public speaking,etiket, pengembangan diri,grooming, make up dan hair styling, pelayanan prima serta kewirausahaan. Dengan mempelajari materi tersebut diatas siswa akan memiliki kemampuan untuk membawa diri dan bersosialisasi dalam masyarakat. Setelah mengikuti pelatihan di Lembaga Kursus dan Pelatihan (LKP) Colour Models Management Yogyakarta, diharapkan siswa tidak hanya memiliki kemampuan dalam bidang modeling, yaitu catwalk, pose (hard skill) menjadi peragawan/wati (catwalk model,) foto model dan model iklan, tetapi siswa juga memiliki kepribadian yang baik (soft skill), yaitu memiliki etiket yang baik, memiliki kemampuan berkomunikasi yang baik, memiliki jiwa sosial yang tinggi, memiliki jiwa kewirausaahan serta mampu membawa diri dalam masyarakat

Menurut Newton (2007, pp.52-74) kepribadian tersusun dari sifat-sifat fisik, bakat, sikap, dan cara-cara berperilaku sebagai berikut: (a). Cara seseorang terlihat, meliputi: tinggi badan, perawakan, warna dan tekstur rambut, ukuran tangan dan kaki, gigi dan mungkin sejumlah sifat-sifat fisik lainnya. (b). Cara seseorang berpakaian, meliputi: kerapian, keserasian, kebersihan, dan gaya baju, topi, sepatu serta assesoris (c). Cara seseorang berbicara, yaitu nada, kualitas dan volume suara .(d). Cara seseorang bersikap secara emosional, meliputi kemampuan seseorang untuk menjaga keseimbangan emosional yang sehat sepanjang waktu.(e) Cara seseorang bersikap secara intelektual, yaitu kemampuan untuk mengambil kesimpulan dari suatu fakta tanpa memasukkan adanya unsur pasangan, tradisi dan kepercayaan buta yang memengaruhi seseorang secara berlebihan. Banyak orang melakukan kesalahan akibat "berpikir dengan perasaan" bukannya otak mereka. (f) Filosofi hidup seseorang, meli- 
puti kode etik dan moralitas pribadi seseorang, konsepsi nilai-nilai dasar dalam kehidupan dan yang lebih luas dari pengertian tersebut adalah perkembangan rohani seseorang.(g) Hal-hal yang dapat seseorang lakukan, yaitu kegiatan atau aktifitas yang seseorang lakukan yang dapat diterima sosial atau bermanfaat. Ini merupakan satu poin dari daya tarik potensial sebagi alat mengembangkan kepribadian.

Pembentukan dan perubahan sikap tidak terjadi dengan sendirinya. Banyak faktor yang mempengaruhinya, diantaranya yaitu: lingkungan dan keluarga. Banyak orang berpendapat bahwa mengajarkan sikap adalah tugas dan tanggung jawab dari orang tua dan lembaga keagamaan. Tetapi sebenarnya lembaga pendidikan formal dan nonformal pun memiliki tugas dalam hal membina sikap, karena pada dasarnya tujuan pendidikan baik di formal maupun nonformal adalah mempengaruhi, membawa, membawa, membimbing anak didik agar memiliki sikap seperti apa yang diharapkan oleh masing-masing tujuan pendidikan. Ahmadi menjelaskan (1991, p.171) bahwa perubahan sikap dipengaruhi oleh faktor intern dan faktor ekstern. (1).Faktor intern: yaitu faktor yang terdapat dalam pribadi manusia itu sendiri. Faktor ini merupakan selectivity atau daya pilih seseorang untuk menerima dan mengolah pengaruh-pengaruh yang datang dari luar; (2). Faktor ekstern: yaitu faktor yang terdapat di luar pribadi manusia. Faktor ini berupa interaksi sosial diluar kelompok. Misalnya: interaksi antara manusia yang dengan hasil kebudayaan manusia yang sampai padanya melalui alat-alat komunikasi seperti: surat kabar, radio, televisi, majalah dan lain sebagainya.

Dari uraian di atas dapat disimpulkan bahwa pembentukan dan perubahan sikap seseorang tidak hanya dari dirinya sendiri tetapi juga dipengaruhi oleh faktor lingkungan yaitu, lingkungan keluarga, masyarakat dan juga lingkungan sekolah.

Program pelatihan memiliki dampak yang positif bagi individu maupun organisasi. Smith (1997 dalam Irianto, 2001, pp.5-6) menguraikan bahwa profil kapabilitas individual berkaitan dengan skills yang diperoleh dari pelatihan. Seiring dengan pengua- saan keahlian atau ketrampilan penghasilan yang akan diterima individu akan meningkat. Pada akhirnya hasil pelatihan ini akan membuka peluang bagi pengembangan karir individu dalam organisasi.

LKP Colour Models Management adalah salah satu divisi usaha dari ASMAT Production Yogyakarta. ASMAT Production berdiri mulai dari tahun 1992. ASMAT adalah singkatan dari Ajang Seni Akting Musik dan Tari. Pada awalnya lembaga ini merupakan sanggar seni, tetapi sejak tahun 2004 berubah menjadi Lembaga Kursus dan Pelatihan (LKP) yang bergerak dalam bidang pelatihan modeling, acting, presenting, menjahit, rias pengantin, dan tata kecantikan kulit dan rambut dibawah naungan Dinas Pendidikan Pemuda dan Olahraga Kabupaten Sleman. Pada tahun 2009 LKP Colour Models Management juga mendapatkan izin operasional dari Dinas Tenaga Kerja dan Transmigrasi Kabupaten Sleman. Selain menyelenggarakan program pelatihan reguler, LKP Colour Models Management juga menyelenggarakan pelatihan yang didanai oleh dana blockgrant Pendidikan Kecakapan Hidup (PKH) Dinas Pendidikan Pemuda dan Olahraga Provinsi Daerah Istimewa Yogyakarta.

Pelatihan modeling yang dikembangkan di Lembaga Kursus dan Pelatihan (LKP) Colour Models Management Yogyakarta adalah modeling plus, dimana materi yang diberikan bukan hanya kemampuan dalam bidang modeling saja (catwalk, pose), akan tetapi juga kemampuan penunjang yang lainnya yaitu, public speaking, pengembangan diri, grooming, etiket, make up $\mathcal{E}$ hair styling, service excelent dan kewirausahaan. Selain itu juga ada kegiatan tambahan yaitu malam keakraban, table manner, dan uji tampil. Pelatihan modeling ini dibagi menjadi dua (2) tingkat, yaitu tingkat dasar dan tingkat terampil. Pelatihan modeling ini ditujukan untuk masyarakat luas usia 3-25 tahun.

Kurikulum yang digunakan dalam lembaga ini adalah kurikulum lokal yang disusun oleh lembaga, dikarenakan untuk pelatihan modeling belum ada Standar Kompetensi Kerja Nasional Indonesia (SKKNI). Pemberian materi catwalk, pose, pengem- 
bangan diri, public speaking, service excellent dan kewirausahaan bertujuan untuk pengembangan aspek personal siswa, sehingga mereka mampu mengembangkan dirinya menjadi pribadi yang lebih baik, sedangkan kegiatan makrab, table manner dan uji tampil bertujuan untuk pengembangan aspek sosial siswa, dalam kegiatan ini mereka berinteraksi langsung dengan teman sesama peserta dan juga orang luar, bahkan dengan dunia kerja yang mungkin nantinya akan mereka geluti.

Dengan pemberian materi di atas diharapkan siswa tidak hanya profesional di bidang modeling, tetapi juga bisa mengembangkan kemampuannya yang lain sehingga nantinya mereka dapat membawa diri dalam kehidupan bermasyarakat.

Tujuan dari penelitian ini adalah untuk mengetahui; (1)Pengelolaan dan pelaksanaan program di Lembaga Kursus dan Pelatihan (LKP) Colour Models Management Yogyakarta. (2) Hasil pengembangan aspek personal dan sosial siswa kursus modeling di Lembaga Kursus dan Pelatihan (LKP) Colour Models Management Yogyakarta. Adapun manfaat dari penelitian ini adalah;

Manfaat teoritis: (1) untuk pengembangan kursus modeling terutama kurikulum dan kompetensi yang dikembangkan dan proses pembelajarannya. (2) pengembangan materi program pembelajaran kursus modeling.

Manfaat Praktis: (1.) Bagi pengelola/ penyelenggara Lembaga Kursus dan pelatihan (LKP) Colour Models Management Yogyakarta merupakan bahan masukan, refleksi, dan evaluasi bagi penyelenggaraan program yang telah dilaksanakan dan juga untuk perbaikan pelaksanaan program-program selanjutnya. (2) Bagi peserta kursus merupakan jawaban keikutsertaannya dalam Lembaga Kursus dan Pelatihan (LKP) Colour Models Management Yogyakarta, sehingga mereka bisa memahami bahwa keikutsertaannya dalam kursus sesuai dengan kebutuhan mereka. (3).Bagi masyarakat sekitar bisa memberikan pemahaman dan gambaran yang nyata tentang peran Lembaga Kursus dan Pelatihan (LKP) Colour Models Management Yogyakarta, sehingga ke depannya mereka menyadari betapa pentingnya pendidikan nonformal bagi kehidupan mereka. (4) Bagi pengembangan Lembaga Kursus dan Pelatihan (LKP) Colour Models Management Yogyakarta, terutama bagi Dinas Pendidikan Pemuda dan Olahraga, Bidang PNFI sebagai pemberi bantuan dana untuk penyelenggaraan program-program Blockgrant di Lembaga Kursus dan Pelatihan (LKP) Colour Models Management Yogyakarta dan juga lembaga-lembaga lainnya.

\section{METODE}

\section{Jenis Penelitian}

Jenis penelitian yang digunakan adalah penelitian kualitatif, karena nantinya data-data yang dihasilkan berbentuk katakata atau bersifat deskriptif.

\section{Waktu dan Tempat Penelitian}

Tempat penelitian yaitu di LKP Colour Models Management Yogyakarta yang beralamat di Jalan. Amerta VII/163 Jombor Kidul Sinduadi, Mlati, Sleman, Yogyakarta. Sedangkan waktu penelitian adalah mulai bulan Maret 2011 sampai dengan September 2011.

\section{Subjek Penelitian}

Subjek dalam penelitian ini adalah siswa, instruktur, staff dan juga kegiatan belajar mengajar di Lembaga Kursus dan Pelatihan (LKP) Colour Models Management Yogyakarta.

\section{Teknik Pengumpulan Data}

Teknik pengumpulan data dalam penelitian ini menggunakan teknik observasi partisipatif, wawancara, dan dokumentasi.(a) Observasi partisipatif. Dalam penelitian ini peneliti merupakan salah satu instruktur di Lembaga Kursus dan Pelatihan (LKP) Colour Models Management Yogyakarta. Sambil melakukan pengamatan, peneliti ikut melakukan apa yang dikerjakan oleh sumber data dan ikut merasakan suka dukanya. Dengan observasi partisipan ini, maka data yang diperoleh akan semakin lengkap, tajam dan sampai mengetahui pada tingkat makna dari setiap perilaku yang tampak. Hal-hal yang akan dioservasi ada- 
lah proses belajar mengajar serta perilaku siswa di Lembaga Kursus dan Pelatihan (LKP) Colour Models Management Yogyakarta.(b) Teknik wawancara. Dengan wawancara, peneliti akan lebih mengetahui hal-hal yang mendalam tentang partisipan, yang tidak diperoleh diperoleh dengan teknik observasi. Susan Stainback (1998 dalam Sugiyono 2009, p.318) mengemukakan bahwa: '...interviewing provide the researcher a means to gain a deeper understanding of how the participant interpret a situation or phenomenon than can't be gained through observation" Jadi dengan wawancara, maka peneliti akan mengetahui hal-hal yang lebih mendalam tentang partisipan dalam menginterpretasikan situasi dan fenomena yang terjadi, dimana hal ini tidak bisa ditemukan melalui observasi. Wawancara ini akan dilakukan kepada siswa, instruktur dan staff di Lembaga Kursus dan Pelatihan (LKP) Colour Models Management Yogyakarta. (c) Teknik Dokumentasi. Teknik ini digunakan untuk mengumpulkan data yang tertulis dari suatu keadaan dan kegiatan subjek penelitian. Teknik dokumentasi ini diperlukan sebagai pelengkap yang dapat menguatkan atau sebagai pengayaan data penelitian yang memiliki hubungan dengan tujuan penelitian, dan interpretasi sekunder terhadap kejadian-kejadian. Data-data yang dikumpulkan adalah catatan non-statistik, seperti tujuan penyelenggaraan pelatihan, kehadiran peserta pelatihan, latar belakang peserta didik (biodata), dan data-data tentang lembaga penyelenggara pelatihan di LKP Colour Models Management Yogyakarta.

\section{Keabsahan Data}

Untuk menguji keabsahan data menurut Sugiyono (2009, p.366) digunakan 4 kriteria yaitu Credibility (validitas internal), transferability (validitas eksternal), dependability (reliabilitas), dan konfirmability (objektifitas).

\section{Teknik Analisis Data}

Peneliti menganalisis data hasil lapangan melalui tahap-tahap sebagai berikut: (1) Koleksi data (data collection), yaitu data hasil observasi, wawancara dan dokumentasi yang dilakukan peneliti dari subjek penelitian dan sumber informasi di LKP Colour Models Yogyakarta, merupakan langkah awal dalam pengolahan data. Dalam mengoleksi data, peneliti melakukan observasi dengan subjek penelitian dan sumber informasi serta mencari dokumentasi hasil pelatihan. Hasil observasi, wawancara dan dokumentasi dengan segera dituangkan peneliti dalam bentuk tulisan dan dianalisis. (2) Penyederhanaan data (data reductional), yaitu penelaahan kembali seluruh catatan hasil observasi, wawancara dan dokumentasi. Dengan demikian pada tahap ini akan diperoleh hal-hal pokok berkaitan dengan fokus penelitian. (3) Penyajian data (data display), merupakan kegiatan penyusunan hal-hal pokok dan pola yang sudah dirangkum secara sistematis, sehingga diperoleh tema dan pola secara jelas tentang permasalahan penelitian agar mudah diambil kesimpulan. (4) Pengambilan kesimpulan dan verifikasi (conclusion; drawing verivying), merupakan upaya untuk mencari makna dari data yang dikumpulkan dan memantapkan kesimpulan dengan member check atau triangulasi yang dilakukan selama dan sesudah data dikumpulkan. Dengan demikian proses verifikasi merupakan upaya mencari makna dari data yang telah dikumpulkan dengan mencari pola, tema, hubungan persamaan, perbedaan-perbedaan, hal-hal yang sering timbul dan lain sebagainya.

Berdasarkan uraian di atas, secara umum analisis data dalam penelitian ini dilakukan melalui tahap-tahap sebagai berikut: (a) Mencatat semua temuan fenomena yang ada di lapangan baik melalui pengamatan, wawancara dan dokumentasi dalam bentuk catatan lapangan. (b) Menelaah kembali catatan hasil pengamatan, wawancara dan studi dokumentasi, serta memisahkan data yang dianggap penting dan tidak penting, tahap ini dilakukan secara berulang-ulang untuk menghindari kekeliruan kalsifikasi. (c) Mendeskripsikan data yang telah diklasifikasikan, untuk kepentingan penelaahan lebih lanjut dengan memperhatikan fokus dan tujuan penelitian. (d) Membuat analisis akhir dari data-data yang sudah diperoleh sebagai hasil dari penelitian. 


\section{HASIL PENELITIAN DAN PEMBAHASAN}

\section{Gambaran Umum Pengelolaan Lembaga \\ Kursus dan Pelatihan (LKP) Colour Models Management Yogyakarta}

LKP Colour Models Management adalah salah satu divisi usaha dari ASMAT Production Yogyakarta. ASMAT Production berdiri mulai dari tahun 1992. ASMAT adalah singkatan dari Ajang Seni Akting Musik dan Tari. Pada awalnya lembaga ini merupakan sanggar seni, tetapi sejak tahun 2004 berubah menjadi Lembaga Kursus dan Pelatihan (LKP) yang bergerak dalam bidang pelatihan modeling, acting, presenting, menjahit, rias pengantin, tata kecantikan kulit dan rambut di bawah naungan Dinas Pendidikan Pemuda dan Olahraga Kabupaten Sleman. Pada tahun 2009 LKP Colour Models Management juga mendapatkan izin operasional dari Models Management beralamat di Jalan Amerta 7/163 Jombor Kidul, Sinduadi, Mlati, Sleman, Yogyakarta. LKP Colour Models Management Yogyakarta memiliki No Induk Lembaga Kursus (NILEK) on line 04104.4.1.0057.39 yang dapat diakses secara nasional. Dengan memiliki NILEK lembaga dapat mengajukan proposal berbagai program yang di selenggarakan oleh Direktorat Jendral Pendidikan Anak Usia Dini Non Formal Informal (PAUDNI) Kementerian Pendidikan dan Kebudayaan. Selain menyelenggarakan program pelatihan reguler, LKP Colour Models Management juga menyelenggarakan pelatihan yang didanai oleh dana blockgrant Pendidikan Kecakapan Hidup (PKH) Dinas Pendidikan Pemuda dan Olah-raga Provinsi Daerah Istimewa Yogyakarta

Siswa untuk program modeling adalah 3-25 tahun, dibagi menjadi 2 kelompok umur yaitu 3-12 tahun dan 13-25 tahun. Proses penjaringan/rekruitmen siswa adalah melalui promo di media cetak (koran), TV lokal, brosur, voucher discount, facebook, website, dan kupon di kalender tahunan LKP Colour Model Management. Persyaratan umum untuk siswa adalah sehat jasmani dan rohani serta tidak terlibat narkoba. Lembaga ini tidak mensyaratkan secara spesifik untuk siswa program modeling, misalnya tinggi badan dan berat badan dikarenakan tidak semua peserta didik yang masuk ke lembaga ini ingin menjadi model professional, tetapi banyak juga yang motivasinya ingin mengembangkan diri mereka, seperti cara berbicara, cara berdandan, etiket, table manner (tata cara di meja makan) dan lain sebagainya.

Sebagai Lembaga Kursus dan Pelatihan yang sudah berdiri sejak tahun 1992, tentu saja LKP Colour Models Management sudah memiliki banyak jaringan kerja sama dengan lembaga mitra. Lembaga-lembaga mitra tersebut ada yang berskala lokal dan nasional. Selain kerja sama dengan lembaga swasta LKP Colour Models Management juga didukung oleh Dinas Pendidikan Pemuda dan Olahraga dan juga Dinas Tenaga Kerja dan Sosial. Bentuk dukungan dari lembaga pemerintah tersebut berupa pemberian izin operasional, workshop peningkatan kualitas pendidik dan tenaga kependidikan, Training of Trainer (TOT), Bimbingan teknis Competency Based Training (CBT) dan lain sebagainya. Selain itu juga dipercaya oleh Dinas Pendidikan Pemuda dan Olahraga Provinsi DIY untuk menyelenggarakan Program Kecakapan Hidup (PKH) bagi remaja yang tidak mampu di wilayah Provinsi DIY. Dukungan stakeholder yang lain adalah dari sekolah formal yaitu dengan penyelenggaraan ekstrakurikuler modeling di Yayasan Al Azhar 31 Yogyakarta, TK Budi Mulia I dan TK/SD Model Sleman. Dukungan juga berasal dari TVRI Yogyakarta yang melibatkan peserta didik LKP Colour Models Management sebagai pengisi acara pada beberapa programnya. Kegiatan seperti ini menjadi media bagi siswa untuk memraktekkan ilmu yang diperoleh di lembaga di dunia kerja.

Penghargaan yang pernah diraih oleh LKP Colour Models Management, baik atas nama lembaga, tenaga pendidik, dan siswa diantaranya adalah : (1) Penghargaan Pendukung TOP Model G-Friends Models Fantasy Gardena Dept. Store, tahun 2004. (2) Penghargaan dari Dinas Pariwisata Provinsi DIY tahun 2009. (3) Penghargaan dari KB-TK Islam Al-Azhar 31 Yogyakarta tahun 2008-2009. (4) Peserta terbaik II Training Of Trainers Tingkat Nasional Implementasi Pedagogi \& Andragogi Pendidik Kursus Direk- 
torat PTK PNF \& HISPPI tahun 2009. (5) Mahda Rayhana (Juara I lomba Modeling Putri SD/SMP/SMA pada lomba Siswa Cerdas Istimewa dan Bakat Istimewa (CI-BI) Tingkat Provinsi tahun 2008. (6) Mahda Rayhana (Peserta Lomba Modeling dalam Gebyar dan Festival Kompetensi Siswa Sekolah Inklusif dan siswa sekolah CI-BI setara SD,SMP, dan SMA tingkat nasional tahun 2008. (7) Rintan Fadilla Ghasani (Juara II lomba Modeling Putri SD/SMP/SMA pada lomba Siswa Cerdas Istimewa dan Bakat Istimewa (CI-BI) Tingkat Provinsi tahun 2008. (8) Mahda Rayhana (Juara III Diajeng SD/MI dalam Kegiatan Lomba Dimas Diajeng Kabupaten Sleman Tahun 2009. (9) Runner-Up II Pemilihan Putri Indonesia Provinsi DIY 2011, atas nama Deasy Damayanti. (10) Finalis Miss Celebrity SCTV 2011, atas nama Nurlita Gadisa Rahmadani dan Fatmawati.

Sebagai Lembaga Kursus dan Pelatihan (LKP) yang mengembangkan aspek sosial siswa, salah satu kegiatan yang dilakukan oleh lembaga adalah program kepedulian lingkungan sosial, misalnya pemberian bantuan ke panti sosial, beasiswa kursus gratis, dan pemberian kalender secara gratis ke masyarakat, kegiatan ini dilaksanakan untuk melatih rasa kepekaan siswa terhadap lingkungan sekitar mereka. Adapun kegiatan sosial yang dilakukan diantaranya adalah sebagai berikut: (1) Pemberian bantuan ke Panti Asuhan Sayap Ibu Yogyakarta dan panti asuhan lainnya tahun 2006,2009, dan 2011. (2) Pemberian beasiswa pelatihan modeling untuk anak dan remaja yang berpotensi tahun 2008-sekarang. (3) Pemberian kalender gratis kepada masyarakat tahun 2009-sekarang. (4) Berpartisipasi aktif dalam kegiatan masyarakat, misalnya kegiatan peringatan HUT Kemerdekaan RI

LKP Colour Models Management Yogyakarta saat ini memiliki 7 orang tenaga pendidik untuk program modeling dan 2 orang tenaga kependidikan. Tenaga pendidik adalah tenaga pengajar/instruktur, sedangkan tenaga kependidikan adalah pengelola lembaga, seperti: pimpinan lembaga, staf administrasi dan staf pemasaran. Pemilihan tenaga kependidikan dilaksanakan dengan penunjukan langsung oleh lem- baga dan juga memasang iklan lowongan pekerjaan. Selain itu LKP Colour Models Management Yogyakarta juga bekerja sama dengan SMK YPKK 1 Sleman, sedangkan untuk tenaga pendidik lembaga menunjuk alumni yang berprestasi. Pada awal masa kerja semua karyawan harus menjalani masa training selama 3 bulan, setelah masa training selesai dan kinerja mereka dianggap memenuhi persayaratan yang ditetapkan lembaga, maka mereka akan menandatangani kontrak kerja sebagai karyawan. Sedangkan untuk evaluasi kinerja tenaga pendidik juga dilaksanakan secara langsung meliputi hasil pembelajaran yang telah dilakukan maupun gaya mengajar para tenaga pendidik.

Selain pemantauan dan evaluasi tenaga pendidik, peningkatan mutu tenaga pendidik dan tenaga kependidikan dilakukan dengan partisipasi pada workshop yang dilaksanakan oleh Dinas Pendidikan Pemuda dan Olahraga, Dinas Tenaga Kerja dan Sosial, Organisasi Mitra HIPKI (Himpunan Penyelenggara Kursus Indonesia), Training of Trainer (TOT), dan melanjutkan studi ke jenjang yang lebih tinggi.

Program pelatihan modeling yang dikembangkan di Lembaga Kursus dan Pelatihan (LKP) Colour Models Management Yogyakarta adalah modeling plus, dimana materi yang diberikan bukan hanya kemampuan dalam bidang modeling saja (catwalk, pose), akan tetapi juga kemampuan penunjang yang lainnya yaitu, public speaking, pengembangan diri, grooming, etiket, make up $\mathcal{E}$ hair styling, dan kewirausahaan. Selain itu juga ada kegiatan tambahan yaitu malam keakraban, table manner (tata cara makan), dan uji tampil. Pelatihan modeling ini dibagi menjadi dua (2) tingkat, yaitu tingkat dasar dan tingkat terampil. Pelatihan ini ditujukan untuk masyarakat luas usia 3-25 tahun. Kurikulum yang digunakan dalam lembaga ini adalah kurikulum lokal yang disusun oleh lembaga, karena untuk pelatihan modeling belum ada Standar Kompetensi Kerja Nasional Indonesia (SKKNI),

Kegiatan belajar mengajar di LKP Colour Models Management Yogyakarta berdasarkan pada kurikulum yang disusun oleh lembaga. Selain itu juga sudah terdapat 
silabus dan rencana pembelajaran untuk setiap pertemuan. Proses pembelajaran berjalan dengan lancar karena materi untuk setiap pertemuan sudah tersusun, seperti yang diamati oleh penulis pada saat berlangsung kelas make up. Pada awal pembelajaran pendidik menjelaskan secara umum tentang tata rias dan fungsinya, kemudian baru ke alat-alat yang digunakan untuk tata rias dan juga urutan dan cara merias yang baik dan benar. Metode yang digunakan pendidik dalam proses pembelajarannya adalah ceramah, tanya jawab dan praktek. Dengan metode ini pendidik lebih bisa memerhatikan satu persatu peserta didiknya dan terjadi komunikasi dua arah antara pendidik dan peserta didik. Pada saat praktek merias pendidik juga berkeliling ke peserta didik, dan memberi kesempatan peserta didik untuk bisa bertanya. Dan di akhir pembelajaran pendidik memberikan evaluasi atau masukan langsung ke peserta didik tentang hasil merias mereka.

Pada umumnya proses belajar mengajar berjalan dengan lancar. Adapun kendala yang terjadi pada proses pembelajaran biasanya dikarenakan ada siswa yang tidak masuk pada materi sebelumnya, sehingga mereka ketinggalan materi, dan terpaksa harus mengulang lagi.

Evaluasi yang dilaksanakan di LKP Colour Models Management terdiri dari evaluasi secara langsung setelah pembelajaran dan evaluasi di akhir program. Evaluasi diakhir program terdiri dari evaluasi tingkat dasar dan evaluasi tingkat terampil. Untuk siswa yang berhasil menyelesaikan pendidikan juga akan mengikuti wisuda siswa yang dilaksanakan satu tahun sekali.

LKP Colour Models Management memiliki ruangan kantor dan ruang latihan yang tergabung dengan rumah tinggal pemilik. Dalam ruang kantor terdapat meja kursi karyawan, pimpinan dan juga meja kursi untuk menerima tamu. Selain itu juga terdapat alat-alat yang dipergunakan untuk kantor pada umumnya, seperti Komputer, printer, mesin fax, televisi dan sebagainya. Di depan ruang kantor terdapat ruang tunggu dan terdapat juga rak-rak yang digunakan untuk menaruh tas dan helm peserta didik. Lembaga ini juga memiliki satu (1) kamar mandi, sedangkan untuk tempat ibadah tidak disediakan, karena lokasi lembaga ini sangat dekat dengan tempat ibadah (masjid). Untuk tempat parkir bisa digunakan untuk parkir 20 motor dan 3 mobil.

Pada lembaga ini ruang teori menjadi satu dengan ruang praktek, untuk setiap pembelajaran ruangan ini mampu menampung 20 peserta didik. Dalam ruangan ini terdapat 2 cermin besar di dinding, 1 papan tulis, 1 tape-vcd player, dan juga media pembelajaran berupa pose-pose foto. Sarana dan prasarana yang dimiliki oleh lembaga ini dirasa cukup mendukung dan memadai untuk proses pembelajaran

\section{Gambaran Umum Siswa LKP Colour Models Management Yogyakarta (Usia 13-25 Tahun)}

Menurut hasil wawancara dengan siswa banyak alasan yang melatarbelakangi mereka sehingga memutuskan untuk mengikuti kursus di LKP Colour Models Management Yogyakarta, diantaranya: ingin menjadi lebih percaya diri, ingin merubah penampilan, ingin belajar berbicara dan ingin menambah banyak teman.

Menurut Kuntoro (2006, p.18) dalam Jurnal Ilmiah, Vol. 1, No. 1, 2006. Visi Pendidik dan Tenaga Kependidikan Pendidikan Non Formal (PTK-PNF). Pendidikan nonformal memiliki fungsi untuk mengembangkan personal dan sosial peserta didik. Setiap orang (individu) selalu hidup dalam konteks bermasyarakat (sosial). Pendidikan yang dipengaruhi pandangan progresivisme melihat tujuan pendidikan bersifat ganda yaitu peningkatan pengembangan diri individu dan sekaligus peningkatan kehidupan sosial yang lebih baik. (Kuntoro, 2006, p.16). Jurnal Ilmiah,Vol. 1, No. 1, 2006. Visi Pendidik dan Tenaga Kependidikan Pendidikan Non Formal (PTK-PNF)).

Peserta didik di LKP Colour Models Management Yogyakarta memiliki latar belakang keluarga dan pendidikan yang beragam. Tentu saja hal ini juga berpengaruh dalam kepribadian mereka. Dari hasil observasi dan wawancara dengan peserta didik sangat terlihat bahwa sebelum mereka mengikuti pelatihan modeling, mereka me- 
rasa kurang percaya diri atau tidak percaya diri, berpenampilan seadanya (terkesan cuek), dan dalam berbicara mereka kurang teratur, dan suara keras.

Menurut Marzuki (2010, pp.90-91) dalam pendidikan nonformal ada dua penekanan dalam upaya mencapai tujuan, yaitu perubahan tingkah laku dan perubahan sosial. Perubahan tingkah laku ditujukan kepada individu-individu anggota masyarakat, yaitu adanya perubahan setelah ada intervensi pemberian pengetahuan, keterampilan, nilai dan sikap. Perubahan yang akan meningkatkan kualitas kerja individu dalam mengatasi masalah dan kebutuhan hidupnya atau kesulitan hidupnya. Penekanan yang kedua adalah perubahan sosial, yaitu perubahan struktur dan peran anggota masyarakat dalam menjalankan fungsi sosial.

Dengan mengikuti pelatihan modeling siswa mengalami banyak perubahan yaitu, dalam penampilan, cara berbicara, cara bersikap dan juga kepercayaan diri yang meningkat. Hal ini yang membuat peserta didik mampu bersosialisasi dengan lingkungan sekitarnya. Pembentukan dan perubahan sikap tidak terjadi dengan sendirinya. Banyak faktor yang memengaruhinya, diantaranya yaitu: lingkungan dan keluarga. Banyak orang berpendapat bahwa mengajarkan sikap adalah tugas dan tanggung jawab dari orang tua dan lembaga keagamaan. Tetapi sebenarnya lembaga pendidikan formal dan nonformal pun memiliki tugas dalam hal membina sikap, karena pada dasarnya tujuan pendidikan baik di formal maupun nonformal adalah memengaruhi, membawa, membawa, membimbing anak didik agar memiliki sikap seperti apa yang diharapkan oleh masing-masing tujuan pendidikan.

Ahmadi menjelaskan (1991, p.171) bahwa perubahan sikap dipengaruhi oleh faktor intern dan faktor ekstern. (1) Faktor intern: yaitu faktor yang terdapat dalam pribadi manusia itu sendiri. Faktor ini merupakan selectivity atau daya pilih seseorang untuk menerima dan mengolah pengaruhpengaruh yang datang dari luar. (2). Faktor ekstern: yaitu faktor yang terdapat di luar pribadi manusia. Faktor ini berupa interaksi sosial di luar kelompok. Misalnya: interaksi antara manusia yang dengan hasil kebudayaan manusia yang sampai padanya melalui alat-alat komunikasi seperti: surat kabar, radio, televisi, majalah dan lain sebagainya.

Dari uraian diatas dapat disimpulkan bahwa pembentukan dan perubahan sikap seseorang tidak hanya dari dirinya sendiri tetapi juga dipengaruhi oleh faktor lingkungan yaitu, lingkungan keluarga, masyarakat dan juga lingkungan sekolah.

\section{Peran Lembaga Kursus dan Pelatihan Modeling LKP Colour Models Management dalam Mengembangkan Aspek Personal dan Sosial Siswa}

Program modeling plus yang diselenggarakan oleh LKP Colour Models Management bertujuan untuk membekali peserta didik tentang ilmu yang tidak dipelajari di sekolah formal, yaitu pemberian soft skill seperti cara berjalan, duduk dan berdiri, cara berdandan, cara berpakaian, cara berbicara dan cara bersikap. Penguasaan keterampilan seperti ini nantinya menciptakan Sumber Daya Manusia (SDM) yang berkualitas yaitu selain memiliki kemampuan akademis yang bagus juga kemampuan penunjang (soft skill).

Dengan demikian LKP Colour Models Management Yogyakarta berperan secara langsung dalam pengembangan Aspek personal dan sosial siswa melalui proses pembelajaran dan kegiatan-kegiatan penunjang yang diselenggarakan, misalnya uji tampil fashion show.

\section{Proses dan Hasil Pengembangan Aspek Personal dan Sosial Siswa LKP Colour Models Management Yogyakarta.}

Setelah mengikuti pelatihan modeling banyak perubahan yang dialami oleh siswa dalam aspek personal diantaranya, yaitu perubahan dari segi penampilan, cara bersikap, cara berbicara, dan rasa percaya diri. Dari beberapa hal tersebut yang paling menonjol adalah perubahan dari penampilan dan cara bersikap (sopan santun). Perubahan di atas menurut Bapak Panji Anom selaku pimpinan lembaga dilaksanakan melalui materi catwalk, public speaking, pengembangan diri, etiket, dan make up. Selain itu 
pengembangan aspek personal juga dilaksanakan melalui pembiasaan disiplin dan berpakaian rapi saat latihan.

Selain perubahan dalam aspek personal siswa juga mengalami perubahan dalam aspek sosialnya, diantaranya yaitu lebih mudah berinteraksi dalam masyarakat atau menyesuaikan diri dalam kehidupan sosial. Berkembangnya aspek sosial juga bisa dilihat dari siswa yang menjadi lebih percaya diri, sehingga mereka lebih mudah berinteraksi dalam masyarakat. Sebagian diantara peserta didik juga berprestasi dalam bidang modeling dan juga mendapatkan pekerjaan dalam bidang hiburan.

Pengembangan aspek sosial juga melalui materi pengembangan diri, public speaking, dan catwalk, karena selain mengembangkan kemampuan personal, materi tersebut juga mengembangkan kemampuan sosial peserta didik dalam berinteraksi dengan orang lain, misalnya berbicara didepan umum. Selain itu pengembangan aspek sosial juga melalui event uji tampil (show) di mall, televisi dan acara lainnya. Dalam kegiatan uji tampil siswa belajar bekerja sama dalam team dan bagaimana menempatkan diri dalam masyarakat.

\section{SIMPULAN DAN SARAN}

\section{Simpulan}

Pengelolaan dan pelaksanaan program pelatihan modeling di Lembaga Kursus dan Pelatihan (LKP) Colour Models Management dapat berjalan lancar sesuai dengan rencana lembaga dan rencana pembelajaran. Program kursus dan pelatihan berlangsung selama $30 \mathrm{x}$ pertemuan terdiri dari $15 \mathrm{x}$ pertemuan tingkat dasar dan $15 \mathrm{x}$ pertemuan tingkat trampil. Evaluasi dilaksanakan sebanyak dua (2) x yaitu evaluasi tingkat dasar dan evaluasi tingkat trampil. Setelah siswa menempuh ujian tingkat trampil dan dinyatakan lulus mereka mengikuti wisuda siswa yang dilaksanakan oleh lembaga. Kendala yang dihadapi dalam proses pembelajaran adalah kurang disiplinnya beberapa siswa dalam mengikuti pembelajaran, misalnya sering tidak masuk atau datang terlambat. Tetapi hal ini dapat diatasi dengan cara siswa mengikuti kelas privat atau kelas khusus.

Lembaga Kursus dan Pelatihan (LKP) Colour Models Management Yogyakarta mengembangkan aspek personal peserta didik melalui materi catwalk, public speaking, pengembangan diri, etiket, dan make up. Setelah mendapatkan materi-materi di atas banyak perubahan yang di alami oleh siswa, diantaranya yaitu perubahan dalam berpenampilan, perubahan dalam berbicara, dan perubahan cara bersikap dalam kehidupan sehari-hari. Dengan perubahan ke arah yang lebih baik membuat siswa menjadi lebih percaya diri.Lembaga Kursus dan Pelatihan (LKP) Colour Models Management Yogyakarta mengembangkan aspek personal peserta didik melalui materi catwalk, public speaking, pengembangan diri, etiket, dan make up. Setelah mendapatkan materi-materi di atas banyak perubahan yang dialami oleh siswa, diantaranya yaitu perubahan dalam berpenampilan, perubahan dalam berbicara, dan perubahan cara bersikap dalam kehidupan sehari-hari. Dengan perubahan kearah yang lebih baik membuat siswa menjadi lebih percaya diri.

Pengembangan aspek sosial siswa di Lembaga Kursus dan Pelatihan (LKP) Colour Models Management melalui program uji tampil (show), melalui program ini siswa belajar bekerja sama dalam team dan belajar berinteraksi dengan orang lain diluar lembaga, misalnya koreografer, penata rias, penata gaya dan sebagainya. Selain melalui program uji tampil pengembangan aspek sosial juga melalui pembelajaran didalam kelas karena proses pembelajaran diikuti oleh siswa yang memiliki beragam karakter. Dengan perbedaan yang ada siswa belajar untuk saling menghargai dan saling menghormati satu sama lainnya. Setelah mengikuti rangkaian kegiatan diatas siswa akan lebih mudah dalam membawa diri/menempatkan diri dalam kehidupan bermasyarakat.

\section{Saran}

Penyelenggaraan pelatihan modeling di Lembaga Kursus dan Pelatihan (LKP) Colour Models Management secara umum dapat berjalan dengan lancar sesuai dengan 
rencana pembelajaran yang ditetapkan oleh lembaga. Manfaat yang diperoleh siswa juga jelas yaitu peningkatan penguasaan kemampuan personal dan sosial siswa sehingga memudahkan mereka dalam kehidupan bermasyarakat. Menurut penulis ada beberapa hal yang harus diperhatikan oleh pengelola lembaga, mengingat manfaat dari program kursus dan pelatihan ini, yaitu: (1). Inovasi kurikulum modeling secara kontinyu, supaya dapat menyesuaikan dengan kebutuhan pasar/peserta didik. (2). Peningkatan kualitas tenaga pendidik dan tenaga kependidikan melalui program workshop, seminar, pelatihan dan melanjutkan sekolah ke jenjang yang lebih tinggi.

\section{DAFTAR PUSTAKA}

Ahmadi, Abu. (1991). Psikologi sosial (edisi revisi). Jakarta: PT. Rineka Cipta

Coombs, P. H \& Ahmed, M. (1974). Attacking rural poverty. Baltimore and London: The John Hopkins University Press.

Darkenwald, G.G. (1982). Adult education: Foundations of practice. New York: Harper \& Row Publisher

Irianto, Jusuf. (2001). Prinsip-prinsip dasar manajemen pelatihan. Surabaya: Insan Cendekia.
Jurnal Ilmiah, Vol. 1, No. 1, 2006. Visi Pendidik dan Tenaga KependidikanPendidikan Non Formal (PTK$P N F)$.

Jurnal Ilmiah, Vol. 1, No. 2, 2006. Visi Pendidik dan Tenaga KependidikanPendidikan Non Formal (PTK$P N F)$.

Marzuki, Saleh. (2010). Pendidikan nonformal. Bandung: PT. Remaja Rosdakarya.

Newton, R. (2007) Great personality plus. (Terjemahan Dariyatno) Yogyakarta: Med Press. (Buku asli diterbitkan tahun 1942).

http://infokursus.net/profil.php (diunduh 28 januari 2011,16.14 WIB)

Sanggarwaty, Ratih, (2003). Kiat menjadi model profesional. Jakarta: PT. Gramedia Pustaka Utama

Sugiyono, (2009). Metode penelitian pendidikan (pendekatan kuantitatif, kualitatif dan RED). Bandung: CV. Alfabeta

Team. (2008).Modul etika dan kepribadian. LKP Colour Models Management ASMAT Pro Yogyakarta. 